\title{
Magnetic Nanofluids: Mechanism of Heat Generation and Transport and Their Biomedical Application
}

\author{
Prem P. Vaishnava and Ronald J. Tackett \\ Additional information is available at the end of the chapter
}

http://dx.doi.org/10.5772/66389

Retraction to: Vaishnava PP, Tackett RJ. Magnetic Nanofluids: Mechanism of Heat Generation and Transport and Their Biomedical Application. In: Sheikholeslami Kandelousi M, editor. Nanofluid Heat and Mass Transfer in Engineering Problems. Rijeka: InTech; 2017. pp. 199-237. DOI: 10.5772/66389

The publisher is retracting [1] due to an attribution dispute. All authors have agreed with the retraction of this chapter.

The publisher regrets any inconvenience this might have caused to the readership.

\section{References}

[1] Vaishnava PP, Tackett RJ. Magnetic Nanofluids: Mechanism of Heat Generation and Transport and Their Biomedical Application. In: Sheikholeslami Kandelousi M, editor. Nanofluid Heat and Mass Transfer in Engineering Problems. Rijeka: InTech; 2017. pp. 199-237. DOI: 10.5772/66389 